\title{
Persistent hyponatraemia following suspected krait envenomation in a 5 year old Sri Lankan child
}

\author{
I Kankananarachchi ${ }^{1}$, M P Fernando ${ }^{2}$, T Denipitiya ${ }^{3}$, P Navabalasooriyar ${ }^{3}$, N C Kitulwatte ${ }^{4}$ \\ Ceylon Medical Journal 2018; 63: 24-25 \\ DOI: http://doi.org/10.4038/cmj.v63i1.8620 \\ (Index words: hyponatraemia; krait; envenomation; child, Sri Lanka)
}

\section{Introduction}

Krait bite (Bungarusc aeruelus) resulting in snake envenomation is a recognized cause of death in Sri Lanka [1]. It is known to cause paralytic respiratory failure and other neurological manifestations [1]. Hyponatraemia following krait envenomation has been reported in some studies [2, 3, 4]. However, there are only a few case reports of severe and persistent hyponatraemia following krait bite [3, 4]. Trint et al. reported hyponatremia (<130 mmol/ L) in 31 out of 42 patients envenomed by Malayan kraits [3]. Hojer et al. reported life threatening hyponatraemia following krait bite as a new syndrome in a young adult [2]. There are no cases reported from Sri Lanka of hyponatraemia following krait envenomation among adults or children.

We report a 5 year old girl with profound and persistent hyponatraemia following a krait bite. which resulted in a convulsion where the above electrolyte abnormality persisted for 10 days. Apart from the facts highlighted above,

\section{Case Report}

A 5-year old girl who was previously well, presented with vomiting and abdominal pain, to a peripheral hospital. She was from Kuliyapitiya which is in the dry zone in North-West Sri Lanka. On admission, she had poor respiratory effort with bilateral ptosis. Further inquiry revealed that she had slept on the floor the previous night. Diagnosis of krait bite was made clinically, due to features of systemic envenomation characterised by neurological involvementas indicated by ptosis. There were no significant local manifestations. She was given 10 vials of anti-venom. Subsequently, she required intubation due to poor respiratory effort. On the same day, the child was transferred to the medical intensive care unit at the Lady Ridgeway Hospital for Children.

On admission she was drowsy and had poor respiratory effort. Therefore, she was continued on artificial ventilation. The serum sodium on day 1 was $145 \mathrm{mmol} / \mathrm{L}$. She was noted to be progressively drowsy despite not administering any sedatives. She developed a convulsion after 36 hours. The serum Na level at the time of convulsion was $118 \mathrm{mmol} / \mathrm{L}$. Serum osmolality was $245 \mathrm{mmol} / \mathrm{L}$ and urine osmolality was $465 \mathrm{mmol} / \mathrm{L}$. Urinary sodium was high (126 mEq/L; normal $20 \mathrm{mEq} / \mathrm{L})$. Her urine output, fractional sodium excretion (0.5\%), renal function and venous blood gas were normal. She was given $3 \% \mathrm{NaCl}$ $5 \mathrm{ml} / \mathrm{kg}$ 4-6 hourly. Fluid restriction was not done as her volume status was already low. Hyponatremia persisted for 10 days (Table 1 ) and eventually she made a complete recovery.

\section{Discussion}

Krait venom consists of a number of proteins such as natriuretic peptides, snake venom metalloproteinases and phospholipase A2 [5]. In this patient with high urinary sodium excretion, normal renal function and normal fractional sodium excretion the urinary salt loss is likely to be due to venom derived natriuretic peptide. Because her volume status remained low we could not restrict fluids. The clinical picture suggests that syndrome of inappropriate antidiuretic hormone (SIADH) is unlikely. However, anti diuretic hormone (ADH) level needs to be investigated to differentiate venom induced natriuresis from SIADH. This test was not performed due to limited facilities.

${ }^{1}$ Department of Paediatrics, Faculty of Medicine, University of Ruhuna, ${ }^{2}$ Department of Paediatrics, Faculty of Medicine, University of Kelaniya, ${ }^{3}$ Medical Intensive Care Unit, Lady Ridgeway Hospital for Children, Colombo 08, Sri Lanka.

Correspondence: IK, e-mail: <imalke462@gmail.com>. Received 06 February 2018 and revised version accepted 18 February 2018.

This is an open-access article distributed under the terms of the Creative Commons Attribution License, which permits unrestricted use, distribution, and reproduction in any medium, provided the original author and source are credited. 
Table 1. Serum electrolyte levels over time

\begin{tabular}{lccccccccccc}
\hline & $\begin{array}{c}\text { Day } \\
01\end{array}$ & $\begin{array}{c}\text { Day } \\
02\end{array}$ & $\begin{array}{c}\text { Day } \\
02\end{array}$ & $\begin{array}{c}\text { Day } \\
03\end{array}$ & $\begin{array}{c}\text { Day } \\
04\end{array}$ & $\begin{array}{c}\text { Day } \\
05\end{array}$ & $\begin{array}{c}\text { Day } \\
06\end{array}$ & $\begin{array}{c}\text { Day } \\
07\end{array}$ & $\begin{array}{c}\text { Day } \\
08\end{array}$ & $\begin{array}{c}\text { Day } \\
09\end{array}$ & $\begin{array}{c}\text { Day } \\
10\end{array}$ \\
\hline $\mathrm{Na}(\mathrm{mEq} / \mathrm{l})$ & 145 & 135 & $\mathbf{1 1 8}$ & 120 & 121 & 127 & 136 & 135 & 131 & 132 & 135 \\
$\mathrm{~K}(\mathrm{mEq} / \mathrm{l})$ & 3.1 & 4.0 & 4.2 & 4.1 & 3.9 & 4.1 & 3.9 & 4.6 & 4.7 & 4.7 & 4.4 \\
\hline
\end{tabular}

Life threatening hyponatremia following krait bite has been described by Hojer in 2010 where a young woman died due to severe hyponatraemia induced cerebral oedema [2]. The lowest Na value was $104 \mathrm{mml} / \mathrm{l}$ at 48 hours and she died after 18 days. The snake species was Bungarus multicinctus. In our patient, the lowest serum $\mathrm{Na}$ was $118 \mathrm{mEq} / \mathrm{L}$ at 36 hours after envenomation. She developed convulsions at this time. However the hyponatraemia did not worsen as she was commenced on $3 \%$ saline which was continued for 10 days until serum $\mathrm{Na}$ levels became normal (Table 1 ).

This report highlights that the hyponatraemia can be fatal [2]. However, in our patient meticulous monitoring in an intensive care setting and management of hyponatraemia with $3 \%$ saline in addition to the use of antivenom resulted in a complete recovery.

Another case has been reported from Thailand where hyponatraemia ( $\mathrm{Na}=129 \mathrm{mEq} / \mathrm{L}$ ) was caused by Malayan krait envenomation in a 6 year old child [4]. However, unlike in this case, he was managed with fluid restriction which is similar to the management of syndrome of inappropriate anti diuretic hormone (ADH) secretion.

In conclusion, this case highlights the profound and the persistent nature of hyponatraemia associated with krait bite which requires frequent monitoring of serum $\mathrm{Na}$ until full recovery.

\section{Acknowledgement}

We would like to acknowledge Prof. S A M Kularathne, Department of Medicine, Faculty of Medicine, University of Peradeniya for assisting us with his expert opinion regarding the clinical management of this patient.

\section{References}

1. Kularatne SA. Common krait (Bungarus caeruleus) bite in Anuradhapura, Sri Lanka: a prospective clinical study, 1996-98. Postgrad Med J 2002; 78(919): 276-80.

2. Höjer J, Tran Hung H, Warrell D. Life-threatening hyponatremia after krait bite envenoming - A new syndrome. ClinToxicol (Phila) 2010; 48(9): 956-7.

3. Trinh KX, Le Khac Q, Trinh LX, Warrell DA. Hyponatraemia, rhabdomyolysis, alterations in blood pressure and persistent mydriasis in patients envenomed by Malayan kraits (Bungarus candidus) in southern Viet Nam. Toxicon 2010 Nov 30; 56(6): 1070-5.

4. Kriengsoontornkij W, Settabut P, Jiranantakann T. Predominant sympathetic activities and hyponatremia in a child with malayan krait envenomation; Asia Pacific Association of Medical Toxicology, poster presentation-32.

5. Rusmili MR, Yee TT, Mustafa MR, Hodgson WC, Othman I. Proteomic characterization and comparison of Malaysian Bungarus candidus and Bungarus fasciatus venoms. $J$ Proteomics 2014; 110: 129-44. 